\title{
Carbon sequestration in clay and silt fractions of Brazilian soils under conventional
}

\section{and no-tillage systems}

\author{
Cecília Estima Sacramento dos Reis ${ }^{1 *}$, Deborah Pinheiro Dick ${ }^{2}$, Jennifer da Silva Caldas ${ }^{1}$, Cimélio Bayer $^{1}$
}

IFederal University of Rio Grande do Sul/Faculty of Agricultural and Life Sciences - Soil Science Dept., Av. Bento Gonçalves, 7712, C.P. 15100 - 91540-000 - Porto Alegre, RS - Brazil.

2Federal University of Rio Grande do Sul/Institute of Chemistry - Physicochemical Dept.

*Corresponding author <ceciliasacramento@gmail.com>

Edited by: Tairone Paiva Leão

\begin{abstract}
The capacity of soils to sequestrate carbon $(C)$ is mainly related to the formation of organo-mineral complexes. In this study, we investigated the influence of soil management systems on the $C$ retention capacity of soil with an emphasis on the silt and clay fractions of two subtropical soils with different mineralogy and climate. Samples from a Humic Hapludox and a Rhodic Hapludox, clayey soils cultivated for approximately 30 years under no-tillage (NT) and conventional tillage (CT) were collected from six layers distributed within 100-cm soil depth from each site and from an adjacent native forest. After the removal of particulate organic matter (POM), the suspension $(<53 \mu \mathrm{m})$ was sonicated, the silt and clay fractions were separated in accordance with Stokes' law and the carbon content of whole soil and physical fractions was determined. In the Humic Hapludox, the clay and silt fractions under NT showed a higher maximum $\mathrm{C}$ retention (72 and $52 \mathrm{~g} \mathrm{~kg}^{-1}$, respectively) in comparison to those under CT (54 and $38 \mathrm{~g} \mathrm{~kg}^{-1}$, respectively). Moreover, the $\mathrm{C}$ concentration increase in both fractions under NT occurred mainly in the topsoil (up to $5 \mathrm{~cm}$ ). The $C$ retention in physical fractions of Rhodic Hapludox varied from 25 to $32 \mathrm{~g} \mathrm{~kg}^{-1}$, and no difference was observed whether under an NT or a CT management system. The predominance of goethite and gibbsite in the Humic Hapludox, as well as its exposure to a colder climate, may have contributed to its greater $\mathrm{C}$ retention capacity. In addition to the organo-mineral interaction, a mechanism of organic matter self-assemblage, enhanced by longer periods of soil non-disturbance, seems to have contributed to the carbon stabilization in both soils.

Keywords: carbon saturation, mineralogy, physical fractionation, soil organic matter, soil profile
\end{abstract}

Received July 18, 2013

Accepted February 10, 2014
Despite a large number of studies regarding the effect of conservative soil management systems on soil $\mathrm{C}$ sequestration, data relating to the role of the clay and silt fraction in retaining $\mathrm{C}$ in subtropical Oxisols are scarce. Some results obtained with temperate soils indicated that for a given soil, maximum $\mathrm{C}$ retention under NT may be greater than under conventional tillage (CT) (Stewart et al., 2007).

In addition to land use and soil parameters, climate was also proven to affect the potential for soil $\mathrm{C}$ storage in French soils, where, in colder regions, the $\mathrm{C}$ retention capacity tends to be greater (Angers et al., 2011). In Brazilian soils, a study about $\mathrm{C}$ sequestration in physical fractions collected up to $17.5 \mathrm{~cm}$ from an agriculture Acrisol, have indicated that the clay fraction tends to show a finite capacity for storing C (Diekow et al., 2005). This study aimed to investigate the relationship between soil management systems and soil type with regard to the potential for soil $\mathrm{C}$ retention at depth of two subtropical soils by focusing on the role of the clay and silt fractions in the $\mathrm{C}$ stabilization process.

\section{Materials and Methods}

$\mathrm{C}$ concentration, soil texture also affects the maximum capacity of $\mathrm{C}$ retention (Six et al., 2002). Fine-textured soils usually present a higher value for maximum $\mathrm{C}$ retention capacity than sandy soils (Angers et al., 2011). This behavior is attributed to a greater available surface area for the organo-mineral interactions shown by the clay and silt fractions (Stewart et al., 2008).

\section{Experimental sites and soil sampling}

The soils investigated in this study belong to long-term experiments located in Guarapuava (Paraná State) and in Santo Ângelo (Rio Grande do Sul State) in southern Brazil (Table 1). The experiments consisted of 
two soil management systems (NT and CT) that were arranged in a randomized complete block design, with three field replications for each management system in Guarapuava and two field replications for each management system in Santo Ângelo (Table 1). The selected soils are both clayey and differ in the mineralogy of the clay fraction and environmental conditions (Table 1).

Soil samples were collected from the $0-2.5,2.5-5$, $5-10,10-20,20-30,30-40,40-60,60-80$ and 80-100 cm layers under $\mathrm{CT}$ and under $\mathrm{NT}$, in all field replications. The samples from an adjacent area (native forest, NF) of each experiment were collected from three random plots, approximately $5 \mathrm{~m}$ apart at the same soil depths to represent the natural soil conditions. The soil samples were air-dried and passed through a 2 -mm sieve.

\section{Soil physical fractionation and carbon concentra- tion analysis \\ Sand $(>53 \mu \mathrm{m})$, silt $(53-2 \mu \mathrm{m})$ and clay $(<2 \mu \mathrm{m})$} fractions were obtained by particle size fractionation. Five grams of soil sample from each field replication were weighed in a $100-\mathrm{mL}$ glass tube, and $50 \mathrm{~mL}$ distilled water was added. In preliminary dispersion tests, the mechanical agitation of the soil sample in distilled water was proven to be inefficient in breaking down the aggregates causing the sieve to clog. Thereafter, $7.5 \mathrm{~g}$ of commercial sand (previously treated with concentrated hydrochloric acid $(\mathrm{HCl})$ to remove possible contaminants and dried at $105^{\circ} \mathrm{C}$ ) were added to the tube.

The suspension was mechanically stirred for $16 \mathrm{~h}$ and passed through a $53-\mu \mathrm{m}$ sieve to separate the particulate organic matter (POM). The fraction $>53 \mu \mathrm{m}$ contained the POM, the soil sand fraction and the added commercial sand particles. Thereafter, the suspension containing the fraction $<53 \mu \mathrm{m}$ was sonicated with the energy needed to attain $95 \%$ dispersion in the Humic Hapludox (1500 $\left.\mathrm{J} \mathrm{mL}^{-1}\right)$ and $99 \%$ dispersion in the Rhodic Hapludox (420 $\mathrm{J} \mathrm{mL}^{-1}$ ) to separate the clay and silt fractions. The respective energy levels were determined in previous testing of each soil separately. The sonicated suspension was transferred to a glass tube, and the volume was completed to $1 \mathrm{~L}$ with distilled water.

Table 1 - Main characteristics of each long-term management experiment and soil.

\begin{tabular}{lll}
\hline Characteristics & \multicolumn{1}{c}{ Guarapuava, PR } & \multicolumn{1}{c}{ Santo Ângelo, RS } \\
\hline Climatic conditions $^{\mathrm{a}}$ & Subtropical (Cfb), $16.5^{\circ} \mathrm{C}$, & Subtropical (Cfa), $19.5^{\circ} \mathrm{C}$, \\
& $2022 \mathrm{~mm} \mathrm{year}^{-1}, 1100 \mathrm{~m}$ a.s.l. & $1850 \mathrm{~mm} \mathrm{year}^{-1}, 300 \mathrm{~m}^{\text {a.s.l. }}$ \\
Coordinates & $25^{\circ} 33^{\prime} \mathrm{S}, 51^{\circ} 29^{\prime} \mathrm{W}$ & $28^{\circ} 16^{\prime} \mathrm{S}, 54^{\circ} 13^{\prime} \mathrm{W}$
\end{tabular}

Year of conversion to agriculture

Management before the experiment

Year of installation

Duration (years) until sampling

Annual $\mathrm{C}$ addition $\left(\mathrm{Mg} \mathrm{ha}^{-1} \text { year }^{-1}\right)^{\mathrm{b}}$

Cropping system

Soil class (Soil taxonomy)e

Soil texture

Particle size distribution in 0-20 $\mathrm{cm}\left(\mathrm{g} \mathrm{kg}^{-1}\right)$

$\mathrm{Fe}_{\mathrm{d}}$ content $\left(\mathrm{g} \mathrm{kg}^{-1}\right)^{\mathrm{g}}$

$\mathrm{Gt} / \mathrm{Gt}+\mathrm{Hm}^{\mathrm{g}}$

$\mathrm{Gb} / \mathrm{Gb}+\mathrm{Kt}^{\mathrm{g}}$

Parent material

aClimate, mean annual temperature, mean annual rainfall and altitude (Cfa: humid subtropical climate with hot summer; Cfb: humid subtropical climate); bMean annual $\mathrm{C}$ addition to soil between no-tillage and conventional tillage systems; 'Costa et al, 2004; 'Dieckow et al., 2009; eSoil Survey Staff (2010); 'Costa et al. (2003); FFe $^{\circ}$ : Citrate-dithionite-extractable Fe; Gt: goethite; Hm: hematite; Gb: gibbsite; Kt: kaolinite (Inda Junior et al., 2007
1964

15 years: wheat-soybean sequential cropping under conventional tillage

1979

25

$2.50^{\mathrm{d}}$

Sequential cropping: wheat-soybean

Rhodic Hapludox

Clayey

711 (clay), 240 (silt), 49 (sand)

87.6

Basalt $\begin{array}{ll}0.79 & 0.03\end{array}$

$\begin{array}{ll}0.74 & 0.00\end{array}$

Sci. Agric. v.71, n.4, p.292-301, July/August 2014 
The clay fraction was separated according to Stokes' law. This fraction was collected successively until its complete removal, leaving behind in the glass tube distilled water and the silt fraction only. Both fractions were flocculated with $1 \mathrm{~mol} \mathrm{~L}^{-1} \mathrm{HCl}$ solution, dried at $60{ }^{\circ} \mathrm{C}$ and finally crushed in a mortar. The proportion of the silt and of the clay fractions was determined gravimetrically. The proportion of the sand fraction (that contains the POM) was obtained by difference of $100 \%$, after discounting the mass of the added commercial sand. The layers $20-30 \mathrm{~cm}, 30-40 \mathrm{~cm}$ and $60-80 \mathrm{~cm}$ were not included in this approach, since their $\mathrm{C}$ content was similar to that of the adjacent soil layers.

In order to verify the presence of light fraction (LF) in the silt fraction (Diekow et al., 2005), a composite silt sample of the field replications was further submitted to density fractionation with sodium polytungstate solution (SPT) at $d=2.0 \mathrm{~g} \mathrm{~cm}^{-3}$. In a glass centrifuge tube, $30 \mathrm{~mL}$ SPT solution and $0.5 \mathrm{~g}$ silt were added, and the suspension was stirred manually five times and submitted to centrifugation for $90 \mathrm{~min}$ at $2000 \mathrm{x} \mathrm{g}$. The supernatant containing the LF was filtered, and the excess SPT solution was removed by washing the LF with $100 \mathrm{~mL}$ distilled water and $100 \mathrm{~mL} 0.01 \mathrm{~mol} \mathrm{~L}^{-1} \mathrm{CaCl}_{2}$ solution. The silt fraction remaining in the tube was centrifuged two times with $80 \mathrm{~mL}$ distilled water for $40 \mathrm{~min}$ at $2000 \mathrm{x}$. The third centrifugation was performed with $80 \mathrm{~mL} 0.01$ mol L-1 $\mathrm{CaCl}_{2}$ solution for $20 \mathrm{~min}$ at $2000 \times \mathrm{g}$, resulting in LF-free silt.

The $\mathrm{C}$ concentration of the whole soil $\left(\mathrm{C}_{\text {soil }}\right), \mathrm{LF}$, silt $\left(\mathrm{C}_{\text {silt }}\right)$ and clay $\left(\mathrm{C}_{\text {clay }}\right)$ fractions was analyzed by dry combustion. The $\mathrm{C}$ concentration of the sand fraction $\left(\mathrm{C}_{\text {sand }}\right)$ was obtained from the difference between the $\mathrm{C}_{\text {soil }}$ and that of $\mathrm{C}_{\text {silt }}+\mathrm{C}_{\text {clay }}$. The $\mathrm{C}$ concentration of the LF-free silt (LF-free $\mathrm{C}_{\text {silt }}$ ) was calculated from the difference between the $\mathrm{C}_{\text {silt }}$ and that of the separated LF. The ratio $\mathrm{C}_{\text {fraction }}$ ' $\mathrm{C}_{\text {soil }}$ that identifies the contribution of each fraction to the $\mathrm{C}$ of the whole soil was calculated based on the $\mathrm{C}$ concentration and the respective weight proportion of each fraction.

The $\mathrm{C}_{\text {silt' }}$ LF-free $\mathrm{C}_{\text {silt }}$ and $\mathrm{C}_{\text {clay }}$ were related to $\mathrm{C}_{\text {soil }}$ for each system studied to investigate the $\mathrm{C}$ distribution in each physical fraction, as well as their $\mathrm{C}$ retention capacity. The exponential data were best fitted to the equations as follows:

$$
\begin{array}{lr}
\mathrm{C}_{\text {fraction }}=\mathrm{a}+\mathrm{b}\left(1-\mathrm{e}^{\left.-\mathrm{CC}_{\text {soil }}\right)}\right. & \text { (Eq. 1) (NF system) } \\
\mathrm{C}_{\text {fraction }}=\mathrm{a}+\left(\mathrm{b} / \mathrm{C}_{\text {soil }}\right) & \text { (Eq. 2) (agricultural systems) }
\end{array}
$$

where $\mathrm{a}, \mathrm{b}$ and $\mathrm{c}$ are constants and $\mathrm{C}_{\text {fraction }}$ and $\mathrm{C}_{\text {soil }}$ are the $\mathrm{C}$ concentrations $\left(\mathrm{g} \mathrm{kg}^{-1}\right)$. The maximum $\mathrm{C}$ retention $\left(\mathrm{C}_{\text {retention }}\right)$ in the clay and silt fractions was calculated from the respective equations assuming $\mathrm{C}_{\text {soil }}$ tending to infinity. The $\mathrm{C}$ saturation deficit $\left(\mathrm{C}_{\mathrm{sd}}\right)$ of a given system and of a given fraction was calculated for each layer $\left(\mathrm{C}_{\text {layer }}\right)$ by the equation $\mathrm{C}_{\text {sd }}=\mathrm{C}_{\text {retention }}-\mathrm{C}_{\text {layer }}$ (Eq. 3), using the resulting curve to estimate the $\mathrm{C}_{\text {layer }}$ in each layer for a given $\mathrm{C}_{\text {soil }}$ value. The $\mathrm{C}_{\mathrm{sd}}$ represents the soil potential for further $\mathrm{C}$ sequestration as a stable form in each system (Angers et al., 2011).

Carbon stock $\left(\mathrm{C}_{\text {stock }}\right)$ in the physical fractions and in the whole soil was calculated by the equivalent soil mass approach (Ellert and Bettany, 1995), taking the soil mass of the NF as a reference.

\section{Carbon resistance and resilience indexes in soil and in physical fractions}

The resistance index $\left(\mathrm{C}_{\text {stock }}\right.$ in $\mathrm{CT} / \mathrm{C}_{\text {stock }}$ in $\left.\mathrm{NF}\right)$ and the resilience index $\left(\mid \mathrm{C}_{\text {stock }}\right.$ in NT $-\mathrm{C}_{\text {stock }}$ in $\left.\mathrm{CT}\right) /\left(\mathrm{C}_{\text {stock }}\right.$ in $\mathrm{NF}-\mathrm{C}_{\text {stock }}$ in CT)) were calculated (Dieckow et al., 2009). The first index describes the capacity of the soil to maintain the $\mathrm{C}_{\text {stock }}$ throughout the disturbances caused by CT implementation, while the second describes the capacity of the soil to recover the $\mathrm{C}_{\text {stock }}$ by the adoption of NT after soil cultivation under $\mathrm{CT}$.

\section{Data analysis}

The experimental data $/ \mathrm{C}$ concentration and ratio $\mathrm{C}_{\text {fraction }} / \mathrm{C}_{\text {soil }}$ l were subjected to analysis of variance and to the Tukey test $(p<0.10)$ to evaluate the significance of the effects of management systems on each soil. The data from native soils were not included in the statistical analysis.

\section{Results and Discussion}

\section{Organic carbon concentration in soil and in physi- cal fractions}

In the Humic Hapludox profiles, the clay content varied between 415 and $526 \mathrm{~g} \mathrm{~kg}^{-1}$ and that of silt between 219 and $325 \mathrm{~g} \mathrm{~kg}^{-1}$ under native forest (data not shown). Under the agricultural soil systems the clay content varied between 393 and $513 \mathrm{~g} \mathrm{~kg}^{-1}$ and that of silt between 153 and $299 \mathrm{~g} \mathrm{~kg}^{-1}$. In the Rhodic Hapludox profiles, the clay content ranged from 568 to $706 \mathrm{~g}$ $\mathrm{kg}^{-1}$ and that of silt from 235 to $307 \mathrm{~g} \mathrm{~kg}^{-1}$ under native forest. Under the agricultural systems, the clay content ranged from 484 to $694 \mathrm{~g} \mathrm{~kg}^{-1}$ and that of silt between 186 to $304 \mathrm{~g} \mathrm{~kg}^{-1}$ (data not shown).

Differences in the $\mathrm{C}$ concentration of whole soil between tillage systems occurred up to $5 \mathrm{~cm}$ depth in the Humic Hapludox (Table 2) and up to $2.5 \mathrm{~cm}$ depth in the Rhodic Hapludox (Table 3$)(p<0.10)$. In both soils, the NT management had higher $\mathrm{C}$ concentration values than those under CT management.The increase in $\mathrm{C}$ concentration promoted by implementation of the NT system in previously cultivated areas under CT has been well-reported (Campos et al., 2011; Jagadamma and Lal, 2010). Considering that the annual biomass addition under both management systems is similar in the two experimental areas, (Table 1), this behavior may be attributed to the maintenance of crop residues on the surface and to the lack of disturbance of the soil under NT, practices that slow down organic matter mineralization (Dieckow et al., 2009). 
Table 2 - Carbon concentration of soil, carbon concentration and $\mathrm{C}_{\text {fraction }} / \mathrm{C}_{\text {soil }}$ ratio in the fractions clay, silt, silt free of light fraction soil organic matter (SOM) and sand in Humic Hapludox under native forest (NF), no-tillage (NT) and conventional tillage (CT).

\begin{tabular}{|c|c|c|c|c|c|c|c|c|c|c|}
\hline \multirow{2}{*}{ System } & \multirow{2}{*}{ Depth } & \multirow{2}{*}{$\mathrm{C}_{\text {soil }}$} & \multicolumn{2}{|c|}{ Clay } & \multicolumn{2}{|c|}{ Silt } & \multicolumn{2}{|c|}{ LF-free silta } & \multicolumn{2}{|c|}{ Sand } \\
\hline & & & C & $\mathrm{C}_{\text {clay }} / \mathrm{C}_{\text {soil }}$ & $\mathrm{C}$ & $\mathrm{C}_{\text {silt }} / \mathrm{C}_{\text {soil }}$ & C & $C_{\text {LF-free silt }} / C_{\text {soil }}$ & C & $\mathrm{C}_{\text {sand }} / \mathrm{C}_{\text {soil }}$ \\
\hline & $\mathrm{cm}$ & $\mathrm{g} \mathrm{kg}_{\text {soil }}{ }^{-1}$ & $\mathrm{~g} \mathrm{~kg}_{\text {fraction }}{ }^{-1}$ & $\%$ & $\mathrm{~g} \mathrm{~kg}_{\text {fraction }}{ }^{-1}$ & $\%$ & $\mathrm{~g} \mathrm{~kg}_{\text {fraction }}{ }^{-1}$ & $\%$ & $\mathrm{~g} \mathrm{~kg}_{\text {fraction }}^{-1}$ & $\%$ \\
\hline \multirow[t]{6}{*}{ NF } & $0-2.5$ & 102.4 & 60.3 & 34 & 76.3 & 19 & $46.9^{b}$ & $8^{b}$ & $191.4(25.2)$ & 47 \\
\hline & $2.5-5$ & 56.9 & 55.5 & 46 & 42.0 & 23 & 27.5 & 11 & 62.5 & 32 \\
\hline & $5-10$ & 45.9 & 49.2 & 57 & 31.2 & 18 & 23.6 & 13 & 58.2 & 25 \\
\hline & $10-20$ & 39.9 & 42.6 & 44 & 22.6 & 16 & 17.5 & 12 & 52.6 & 40 \\
\hline & $40-60$ & 23.2 & 29.7 & 54 & 11.6 & 16 & 9.2 & 13 & 34.2 & 30 \\
\hline & $80-100$ & 26.1 & 24.4 & 61 & 5.3 & 15 & 4.7 & 6 & 17.3 & 34 \\
\hline \multirow[t]{6}{*}{ NT } & $0-2.5$ & $58.5 \mathrm{a}$ & $56.3 \mathrm{a}$ & $39 a$ & $51.0 \mathrm{a}$ & $25 a$ & 41.9 & 19 & $69.3 \mathrm{a}$ & 37 a \\
\hline & $2.5-5$ & $56.8 \mathrm{a}$ & $57.0 \mathrm{a}$ & $42 \mathrm{~b}$ & $47.8 \mathrm{a}$ & $26 \mathrm{a}$ & 41.6 & 21 & $61.3 \mathrm{a}$ & $41 \mathrm{a}$ \\
\hline & $5-10$ & 45.7 a & $50.9 a$ & $50 \mathrm{a}$ & $38.6 \mathrm{a}$ & $25 a$ & 33.6 & 22 & $46.1 \mathrm{a}$ & 32 a \\
\hline & $10-20$ & $40.4 \mathrm{a}$ & $44.3 \mathrm{a}$ & $52 \mathrm{a}$ & $31.2 \mathrm{a}$ & $19 a$ & 27.8 & 17 & $41.7 \mathrm{a}$ & $29 a$ \\
\hline & $40-60$ & $25.4 \mathrm{a}$ & $30.4 \mathrm{a}$ & $48 \mathrm{a}$ & $23.2 \mathrm{a}$ & $16 \mathrm{a}$ & 18.4 & 15 & $22.6 \mathrm{a}$ & $36 a$ \\
\hline & $80-100$ & $18.3 \mathrm{a}$ & $18.9 \mathrm{a}$ & $41 \mathrm{a}$ & $11.7 \mathrm{a}$ & $10 \mathrm{a}$ & 8.7 & 10 & $32.2 \mathrm{a}$ & $48 a$ \\
\hline \multirow[t]{6}{*}{ CT } & $0-2.5$ & $38.6 \mathrm{~b}$ & $45.0 \mathrm{a}$ & 57 a & $34.2 \mathrm{~b}$ & $23 a$ & 29.8 & 20 & $27.2 \mathrm{~b}$ & $28 b$ \\
\hline & $2.5-5$ & $40.0 \mathrm{~b}$ & $44.4 \mathrm{~b}$ & $49 a$ & $34.2 \mathrm{~b}$ & $22 \mathrm{a}$ & 30.4 & 19 & $38.0 \mathrm{~b}$ & $29 b$ \\
\hline & $5-10$ & 39.3 a & $45.1 \mathrm{a}$ & $50 \mathrm{a}$ & $33.8 \mathrm{a}$ & $23 \mathrm{a}$ & 29.1 & 19 & $35.8 \mathrm{~b}$ & $27 \mathrm{a}$ \\
\hline & $10-20$ & $38.6 \mathrm{a}$ & $44.4 \mathrm{a}$ & $51 \mathrm{a}$ & $33.7 \mathrm{a}$ & $21 \mathrm{a}$ & 29.1 & 18 & $34.1 \mathrm{a}$ & $28 a$ \\
\hline & $40-60$ & $22.3 \mathrm{a}$ & $31.0 \mathrm{a}$ & $60 \mathrm{a}$ & $19.4 \mathrm{~b}$ & $11 \mathrm{~b}$ & 17.1 & 10 & $19.7 \mathrm{a}$ & $30 \mathrm{a}$ \\
\hline & $80-100$ & $9.3 \mathrm{~b}$ & $10.4 \mathrm{~b}$ & $50 \mathrm{a}$ & $4.5 \mathrm{~b}$ & $14 \mathrm{a}$ & 3.6 & 9 & $10.3 \mathrm{a}$ & $45 a$ \\
\hline
\end{tabular}

Mean values followed by the same low case letter do not differ between management systems at the same depth ( $p<10 \%$ ); a Silt fraction free of SOM light fraction; bValues obtained from a composite sample of field replications for each system, therefore no statistical test was performed.

Compared to the $\mathrm{NF}$, the $\mathrm{C}$ concentration under NT management in the Humic Hapludox was lower only in the first $2.5 \mathrm{~cm}$ of depth; this is most likely due to the thick layer of litter found under native forests (Potes et al., 2012). In contrast, in the Rhodic Hapludox, the NF had greater $\mathrm{C}$ values than those of the agricultural areas up to a depth of $20 \mathrm{~cm}$, indicating that the adverse effects of 15 years under CT management on the soil C retention had not been overcome after 25 years of NT management (Table 3).

The higher resistance of the Humic Hapludox in losing $\mathrm{C}$ due to the introduction of agriculture cannot be attributed in this study to the texture, as was proposed by Dieckow et al. (2009), because the two soils investigated are clayey (Table 1). More likely, in our study, the higher temperature in the summer in the Santo Ângelo region (where it can reach $35^{\circ} \mathrm{C}$ ) in comparison to that of Guarapuava enhances the mineralization of the residues in the Rhodic Hapludox, causing not only lower soil $\mathrm{C}$ concentrations under NF but also lower $\mathrm{C}$ concentrations under NT management. An additional factor that may explain the different behavior observed in both soils may be their different mineralogy. The Humic Hapludox, richer in goethite and gibbsite than the Rhodic Hapludox (Table 1), presents a high density of reactive sorptive sites (Kaiser and Guggenberger, 2000) and, thus, stabilizes the soil organic matter (SOM) through more effective organo-mineral interactions. In addition to its lower surface area, the denser structure of hematite in comparison to goethite leads to lower reactivity of the surface hydroxyl groups (Schwertmann and Taylor, 1977).

In the Humic Hapludox, the $\mathrm{C}$ concentration in the clay fraction $\left(\mathrm{C}_{\text {clay }}\right)$ ranged between 10 and $60 \mathrm{~g} \mathrm{~kg}^{-1}$ with the exception of the $0-2.5 \mathrm{~cm}$ layer from $\mathrm{NF}_{\text {, and }}$ it was always greater than the values observed for the respective silt fraction $\left(\mathrm{C}_{\text {silt }}\right)$ (Table 2$)$, regardless of the soil use. After the removal of the LF, the C concentration of the silt fraction (LF-free $\mathrm{C}_{\text {silt }}$ ) decreased down to $100 \mathrm{~cm}$ in all three sites of the Humic Hapludox, demonstrating the contribution of SOM particulate in deeper layers. In the specific case of the $0-2.5 \mathrm{~cm}$ layer from $\mathrm{NF}$, the greater LF-free $\mathrm{C}_{\text {silt }}$ concentration compared to that of NT is attributable to the POM derived from the forest litter.

The higher values of $\mathrm{C}_{\text {clay }}$ compared to those observed for the LF-free silt fraction are attributable to the greater surface area available for the organo-mineral interactions in the clay fraction. Regarding the two management systems, $\mathrm{C}_{\text {clay }}$ and mineral-associated silt SOM (LF-free $\mathrm{C}_{\text {silt }}$ ) under NT management were greater than that under CT management up to a depth of $2.5 \mathrm{~cm}$ (Table 2).

Carbon concentration in the sand fraction $\left(\mathrm{C}_{\text {sand }}\right)$ of the Humic Hapludox was greater than the $\mathrm{C}_{\text {silt }}$ at all depths under NF that were analyzed (Table 2), indicating that throughout this long period of undisturbed land use, the POM (that occurs in the sand fraction) had also accumulated in deeper layers. Under NT management, the $\mathrm{C}_{\text {sand }}$ was greater than the $\mathrm{C}_{\text {silt }}$ up to a depth of $10 \mathrm{~cm}$, 
Table 3 - Carbon concentration of soil, carbon concentration and $\mathrm{C}_{\text {fraction }} / \mathrm{C}_{\text {soil }}$ ratio in the fractions clay, silt, silt free of light fraction soil organic matter (SOM) and sand in Rhodic Hapludox under native forest (NF), no-tillage (NT) and conventional tillage (CT).

\begin{tabular}{|c|c|c|c|c|c|c|c|c|c|c|}
\hline \multirow{2}{*}{ System } & \multirow{2}{*}{ Depth } & \multirow{2}{*}{$\mathrm{C}_{\text {soil }}$} & \multicolumn{2}{|c|}{ Clay } & \multicolumn{2}{|c|}{ Silt } & \multicolumn{2}{|c|}{ LF-free silta } & \multicolumn{2}{|c|}{ Sand } \\
\hline & & & $C$ & $\mathrm{C}_{\text {clay }} / \mathrm{C}_{\text {soil }}$ & $C$ & $\mathrm{C}_{\text {silt }} / \mathrm{C}_{\text {soil }}$ & $C$ & $C_{\text {LF-free sith }} / C_{\text {soil }}$ & C & $C_{\text {sand }} / C_{\text {soil }}$ \\
\hline \multirow{7}{*}{$\mathrm{NF}$} & $\mathrm{cm}$ & $\mathrm{g} \mathrm{kg}_{\text {soil }}{ }^{-1}$ & $\mathrm{~g} \mathrm{~kg}_{\text {fraction }}{ }^{-1}$ & $\%$ & $\mathrm{~g} \mathrm{~kg}_{\text {fraction }}{ }^{-1}$ & $\%$ & $\mathrm{~g} \mathrm{~kg}_{\text {fraction }}{ }^{-1}$ & $\%$ & $\mathrm{~g} \mathrm{~kg}_{\text {fraction }}{ }^{-1}$ & $\%$ \\
\hline & $0-2.5$ & 71.4 & 41.6 & 34 & 66.3 & 30 & $50.6^{b}$ & $20^{\mathrm{b}}$ & 198.2 & 36 \\
\hline & $2.5-5$ & 47.9 & 37.9 & 46 & 50.8 & 31 & 38.5 & 23 & 104.4 & 24 \\
\hline & $5-10$ & 32.0 & 31.6 & 58 & 34.3 & 30 & 27.7 & 23 & 24.1 & 12 \\
\hline & $10-20$ & 22.7 & 26.1 & 68 & 21.5 & 27 & 17.1 & 22 & 14.9 & 5 \\
\hline & $40-60$ & 12.1 & 14.0 & 76 & 11.9 & 22 & 9.7 & 19 & 6.0 & 2 \\
\hline & $80-100$ & 8.2 & 9.9 & 76 & 8.2 & 22 & 6.9 & 20 & 3.5 & 5 \\
\hline \multirow[t]{6}{*}{ NT } & $0-2.5$ & $30.0 \mathrm{a}$ & $23.6 \mathrm{a}$ & $43 a$ & $34.2 \mathrm{a}$ & $36 a$ & 30.5 & 30 & $32.6 \mathrm{a}$ & $22 \mathrm{~b}$ \\
\hline & $2.5-5$ & $24.5 \mathrm{a}$ & $21.3 \mathrm{a}$ & $50 a$ & $25.8 \mathrm{a}$ & $31 \mathrm{a}$ & 21.3 & 25 & $34.0 \mathrm{a}$ & $19 a$ \\
\hline & $5-10$ & $20.2 \mathrm{a}$ & $21.0 \mathrm{a}$ & $57 \mathrm{a}$ & $20.3 b$ & $28 \mathrm{a}$ & 16.7 & 24 & $26.4 \mathrm{a}$ & $15 \mathrm{a}$ \\
\hline & $10-20$ & $17.4 \mathrm{a}$ & $19.4 \mathrm{a}$ & $65 a$ & $16.4 \mathrm{a}$ & $26 a$ & 13.7 & 22 & $12.3 \mathrm{a}$ & $15 \mathrm{a}$ \\
\hline & $40-60$ & $11.8 \mathrm{a}$ & $14.2 \mathrm{a}$ & $78 \mathrm{a}$ & $10.3 \mathrm{a}$ & $20 \mathrm{a}$ & 8.7 & 18 & $6.2 \mathrm{a}$ & $4 a$ \\
\hline & $80-100$ & $8.4 \mathrm{a}$ & $9.7 \mathrm{a}$ & $76 a$ & $7.6 \mathrm{a}$ & $18 \mathrm{a}$ & 5.7 & 14 & $12.2 \mathrm{a}$ & $13 \mathrm{a}$ \\
\hline \multirow[t]{6}{*}{ СT } & $0-2.5$ & $23.1 \mathrm{~b}$ & $19.5 \mathrm{~b}$ & $40 \mathrm{a}$ & $26.9 \mathrm{~b}$ & $34 \mathrm{a}$ & 24.1 & 30 & $27.5 \mathrm{a}$ & $26 \mathrm{a}$ \\
\hline & $2.5-5$ & $22.1 \mathrm{a}$ & $19.8 \mathrm{a}$ & $46 \mathrm{a}$ & $25.6 \mathrm{a}$ & $33 a$ & 21.5 & 29 & $34.8 \mathrm{a}$ & $22 \mathrm{a}$ \\
\hline & $5-10$ & $20.9 a$ & $20.2 \mathrm{a}$ & $56 \mathrm{a}$ & $24.4 \mathrm{a}$ & $35 a$ & 21.1 & 30 & $13.7 \mathrm{a}$ & $9 \mathrm{~b}$ \\
\hline & $10-20$ & $17.1 \mathrm{a}$ & $18.0 \mathrm{a}$ & $60 \mathrm{a}$ & $18.5 \mathrm{a}$ & $31 \mathrm{a}$ & 16.2 & 27 & $16.0 \mathrm{a}$ & $13 \mathrm{a}$ \\
\hline & $40-60$ & $10.9 \mathrm{a}$ & $13.1 \mathrm{a}$ & $77 \mathrm{a}$ & $9.0 \mathrm{a}$ & $21 \mathrm{a}$ & 6.4 & 14 & $7.1 \mathrm{a}$ & $10 \mathrm{a}$ \\
\hline & $80-100$ & $7.5 \mathrm{a}$ & $9.2 \mathrm{a}$ & $76 a$ & $6.6 \mathrm{a}$ & $16 \mathrm{a}$ & 5.4 & 13 & $7.0 \mathrm{~b}$ & $14 \mathrm{a}$ \\
\hline
\end{tabular}

Mean values followed by the same low case letter do not differ between management systems at the same depth ( $p<10 \%$ ); a Silt fraction free of SOM light fraction; bValues obtained from a composite sample of field replications for each system, therefore no statistical test was performed.

while under CT management, no difference in $\mathrm{C}$ concentration between the two fractions was observed (Table 2). This contrasting behavior between the soil management systems highlights the surface and sub-surface accumulation of POM under NT management after 25 years, due to the lack of revolvement of the soil at the ploughing depth of $20 \mathrm{~cm}$.

Rhodic Hapludox had a different behavior regarding the $\mathrm{C}$ concentration in the fractions among the land uses. Under $\mathrm{NF}$, the $\mathrm{C}_{\text {silt }}$ was greater than the $\mathrm{C}_{\text {clay }}$ only in the first $2.5 \mathrm{~cm}$, and this difference faded after the removal of the LF fraction from the silt (Table 3). The $\mathrm{C}_{\text {sand }}$ values were greater than in the other fractions up to a depth of $5 \mathrm{~cm}$ under NF and in the 2.5-5 cm layer under NT and CT managements. At layers deeper than $5 \mathrm{~cm}$, the $\mathrm{C}_{\text {sand }}$ values were smaller than those of the $\mathrm{C}_{\text {clay }}$ and $\mathrm{C}_{\text {silt }}$, indicating that in contrast to the Humic Hapludox, no accumulation of light-free SOM along the profile occurred in this soil. The greater precipitation in the region of Guarapuava (Table 1) compared to the Santo Ângelo region may promote the translocation of light-free SOM through deeper layers. Additionally, in the Rhodic Hapludox under NT and CT managements, the LF-free $\mathrm{C}_{\text {silt }}$ tended to surpass the $\mathrm{C}_{\text {clay }}$ up to depths of $2.5 \mathrm{~cm}$ and $5 \mathrm{~cm}$, respectively, showing unexpected behavior considering the greater surface area of the clay fraction. From $20 \mathrm{~cm}$ downwards, the opposite trend was observed (Table 3).

In general, in the Humic Hapludox, the proportions of $\mathrm{C}_{\text {clay }} / \mathrm{C}_{\text {soill }}$ LF-free $\mathrm{C}_{\text {silt }} / \mathrm{C}_{\text {soil }}$ and $\mathrm{C}_{\text {sand }} / \mathrm{C}_{\text {soil }}$ varied from 30 to $60 \%, 6$ to $22 \%$ and 25 to $48 \%$, respectively (Table 2). In the Rhodic Hapludox, the proportion of $\mathrm{C}_{\text {clay }} / \mathrm{C}_{\text {soil }}$ was greater (34 to $78 \%$ ) than that in the Humic Hapludox and increased steadily with depth (Table 3). The LF-free $\mathrm{C}_{\text {silt }} / \mathrm{C}_{\text {soil }}$ and $\mathrm{C}_{\text {sand }} / \mathrm{C}_{\text {soil }}$ proportions in the Rhodic Hapludox were always smaller than $\mathrm{C}_{\text {clay }} / \mathrm{C}_{\text {soil }}$.

\section{Predicted capacity of carbon retention and carbon} saturation deficit in silt and clay fractions

The determination coefficients obtained for the relationship between the $\mathrm{C}_{\text {fraction }}$ and $\mathrm{C}_{\text {soil }}$ (Figure 1) varied between 0.93 to 0.99 for the clay fraction, 0.79 to 0.95 for the silt fraction and 0.87 to 0.99 for the LF-free silt fraction. In general, the curves obtained from the experimental data tended to a saturation plateau for the agricul-


silt fractions presented a steady increase. Although some curves showed also a linear relationship (NF curves and Figures $1 \mathrm{c}$ and $1 \mathrm{e})$, for the following discussion of the predicted capacity of maximum $\mathrm{C}$ retention, the parameters obtained from either exponential or inverse first order polynomial fitting will be used. In this way we assume that all fractions will present a $\mathrm{C}$ saturation level.

In the Humic Hapludox, the predicted capacity for the maximum $\mathrm{C}$ retention $\left(\mathrm{C}_{\text {retention }}\right)$ in the clay fraction, estimated from the mathematical model applied, varied from 54 to $72 \mathrm{~g} \mathrm{~kg}^{-1}$ and increased in the order $\mathrm{CT}<\mathrm{NF}<\mathrm{NT}$ (Figure 1). Under $\mathrm{NF}$, the maximum $\mathrm{C}_{\mathrm{re}}$ for the silt fraction was greater than that for the clay fraction; this trend remained even after the removal 

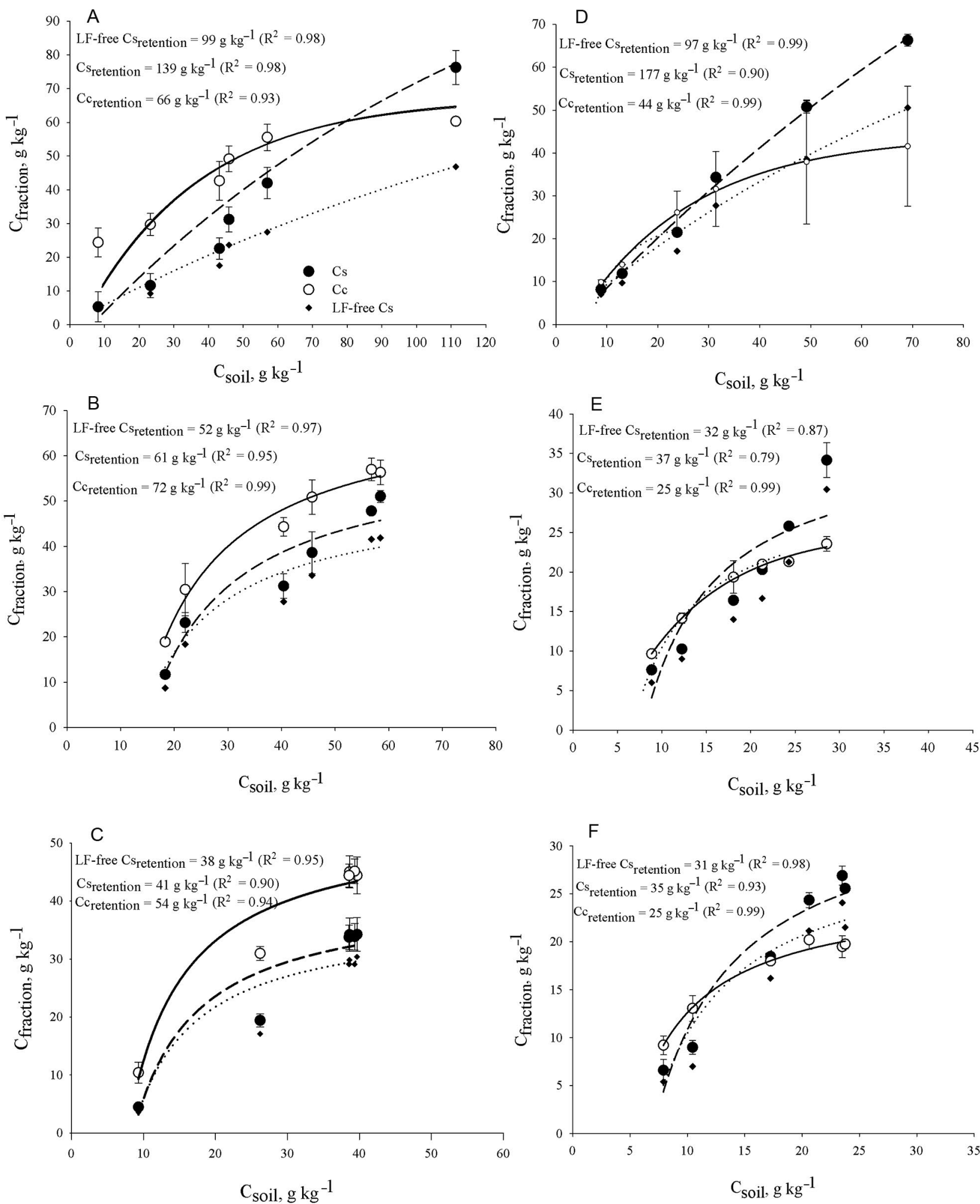

Figure 1 - Relationship between the $\mathrm{C}_{\text {fraction }}$ and $\mathrm{C}_{\text {soil }}$ for clay (CC), silt (CS) and silt fraction free of soil organic matter (SOM) light fraction (LF-free $\mathrm{Cs}$ ) in the Humic Hapludox under native forest (A), no-tillage (B) and conventional tillage (C) and in the Rhodic Hapludox under native forest (D), no-tillage $(E)$ and conventional tillage $(F)$. The $C c_{\text {retention, }} \mathrm{Cs}_{\text {retention }}$ and LF-free $C s_{\text {retention }}$ are the maximum $C$ retention in clay, silt and LF-free silt, respectively, estimated by the applied mathematical model. 
of the LF fraction (Figure 1). For agricultural uses, the maximum $\mathrm{C}_{\text {retention }}$ for the clay fraction was greater than that for the silt and for the LF-free silt, as expected. However, the value of the maximum $\mathrm{C}_{\text {retention }}$ obtained for a given $\mathrm{C}$ fraction under NT management was always greater than that found for the respective fraction under CT management in this soil. Because the density of the mineral sorptive sites of a given fraction depends on its mineralogy and not on the management system, similar values for the $\mathrm{C}_{\text {retention }}$ for a given fraction were expected, regardless of the soil use.

The $\mathrm{C}_{\text {retention }}$ obtained for the $\mathrm{C}$ fractions under $\mathrm{NF}$ of the Rhodic Hapludox decreased in the order LF-free silt $>$ silt $>$ clay (Figure 1), showing the same trend observed for the NF of the Humic Hapludox. However, in contrast to the soil from Guarapuava, the $\mathrm{C}_{\text {retention }}$ for the $\mathrm{C}$ fractions under agricultural use had the same trend as under $\mathrm{NF}$, and no difference was observed between management systems (Figure 1).

Two mechanisms of SOM stabilization can be proposed, based on the following results: the greater $\mathrm{C}_{\text {reten- }}$ tion values found for the NF systems compared to their respective agricultural use, the greater $\mathrm{C}_{\text {retention }}$ values found for the $\mathrm{C}$ fractions under NT management compared to those under CT management for the Humic Hapludox, and the higher capacity of LF-free silt in retaining SOM than the clay fraction under NF and under NT and CT managements in the Rhodic Hapludox. It seems that the accumulation of $\mathrm{C}$ in a given fraction is not solely governed by a surface phenomenon; i.e., it does not only depend on the available sorptive sites and their affinity for the SOM. Most likely a mechanism of self assemblage, as proposed by Kleber et al. (2007), contributes to the retention of $\mathrm{C}$ in the fractions of the two soils studied. In that model, three zones for the SOM are proposed. In the first zone, the SOM is directly sorbed on the mineral surface via its hydrophilic groups. In the second zone, the hydrophobic groups of the sorbed SOM constitute a new sorbing surface for the rest of the SOM via hydrophobic and hydrophilic groups, resulting in a self-assemblage of the SOM. The third zone, located at the most external part of this organo-mineral assemblage, is called the kinetic zone and interacts with cations via hydrophilic groups.

Our hypothesis is that in the two soils under NF management, the long period of non-disturbance of the soil enables the establishment of such interactions, which seems to contribute mainly to the retention of $\mathrm{C}$ in the silt fraction regardless of the mineralogy, as indicated by the similarity of the $\mathrm{C}_{\text {retention }}$ obtained for the LF-free silt in the two soils (Figure 1). In the Humic Hapludox under NT management, the lack of disturbance of the soil also favors the retention of the SOM organized in self-assemblage, resulting in a greater value of $\mathrm{C}_{\text {retention }}$ in the silt and clay fractions under NT management compared to CT management. Conversely, the climatic conditions in the Rhodic Hapludox (i.e., the dryer and hotter summer) would enhance the oxidation of the SOM and the formation of hydrophobic bonds would not be favored; therefore, this mechanism would be less relevant than in the Guarapuava soil.

All maximum $\mathrm{C}_{\text {retention }}$ values for the $\mathrm{C}$ fractions under agricultural use obtained for the Rhodic Hapludox were always smaller than those calculated for the Humic Hapludox, indicating that the available surface for the organo-mineral interactions in the latter has a higher affinity for the sorption of the SOM. As discussed earlier, the higher content of goethite and the presence of gibbsite in the Humic Hapludox should probably account for this result.

The effect of soil use and management on the distribution of the light-free SOM in the silt fraction seems not to be affected by the soil type. In both soils, the contribution of the light SOM fraction to the $\mathrm{C}_{\text {silt }}$ was approximately 40 to $50 \%$ under NF, $20 \%$ under NT and $10 \%$ under CT managements.

Values of $\mathrm{C}$ saturation deficit $\left(\mathrm{C}_{\mathrm{sd}}\right)$, calculated as $\mathrm{C}$ concentration, were obtained for the $\mathrm{NF}$ environments and ranged from 2.8 to $38 \mathrm{~g} \mathrm{~kg}^{-1}$ in the clay fraction and from 45 to $89 \mathrm{~g} \mathrm{~kg}^{-1}$ in the LF-free silt fraction and did not differ between the two soils (Tables 4 and 5). A different situation occurred with the agricultural systems. In the Humic Hapludox, $\mathrm{C}_{\text {sd }}$ varied from 10 to $52 \mathrm{~g} \mathrm{~kg}^{-1}$ in the clay fraction and from 8 to $38 \mathrm{~g} \mathrm{~kg}^{-1}$ in the LFfree silt fraction, whereas for the Rhodic Hapludox, the range was narrower: 1.8 to $16 \mathrm{~g} \mathrm{~kg}^{-1}$ in the clay fraction and 8 to $27 \mathrm{~g} \mathrm{~kg}^{-1}$ in the LF-free silt fraction (Table 5). The values obtained for the Rhodic Hapludox are in the range of that estimated for French agricultural soils with similar clay + silt content, which reached up to approximately $30 \mathrm{~g} \mathrm{~kg}^{-1}$ (Angers et al., 2011). In Brazilian soils, values such as $32 \mathrm{~g} \mathrm{C} \mathrm{kg}_{\text {clay }}{ }^{-1}$ and $48 \mathrm{~g} \mathrm{C} \mathrm{kg}_{\text {clay }}{ }^{-1}$ for $\mathrm{C}$ saturation deficit were found for a Rhodic Hapludox and a Red Acrisol, respectively (Diekow et al., 2005; Roscoe et al., 2001).

Considering that texture and density influence the potential of a given soil in further $\mathrm{C}$ storage, we calculated the $\mathrm{C}$ saturation deficit in terms of $\mathrm{C}$ stocks. In this way, the contribution of a given fraction to the whole soil is also accounted for in the $\mathrm{C}_{\mathrm{sd}}$ value. The $\mathrm{C}_{\text {sd }}$ in terms of $\mathrm{C}$ stocks increased with depth in both soils under native vegetation systems (Table 4). For the Humic Hapludox profile, $128 \mathrm{Mg} \mathrm{C} \mathrm{ha}^{-1}$ for the clay fraction and $195 \mathrm{Mg}$ $\mathrm{C} \mathrm{ha}{ }^{-1}$ for the LF-free silt fractions were calculated (Table 4), and for the Rhodic Hapludox profile, the values were $196 \mathrm{Mg} \mathrm{C} \mathrm{ha}^{-1}$ for the clay fraction and $227 \mathrm{Mg} \mathrm{C}$ $\mathrm{ha}^{-1}$ for the LF-free silt fraction (Table 5). These values are relatively high and represent a hypothetical situation where the whole profile would accumulate $\mathrm{C}$ in a homogeneous way. In fact, Angers et al. (2011) reported that the theoretical $\mathrm{C}$ saturation equation may lead to an overestimation of the capacity of a soil to store a stable $\mathrm{C}$ fraction. Therefore, as the SOM dynamics at the surface differ from those in deeper layers and the native vegetation represents an equilibrium state regarding SOM turnover, we decided to evaluate the $\mathrm{C}$ saturation deficit 
Table 4 - Carbon stock and carbon saturation deficit in clay and LF-free silt fractions of a Humic Hapludox under native forest (NF), no-tillage (NT) and conventional tillage (CT) (values in parentheses refer to the standard deviation).

\begin{tabular}{|c|c|c|c|c|c|c|c|}
\hline \multirow{3}{*}{ System } & \multirow{3}{*}{$\begin{array}{c}\text { Depth } \\
\mathrm{Cm}\end{array}$} & \multicolumn{3}{|c|}{ Clay } & \multicolumn{3}{|c|}{ LF-free silt } \\
\hline & & \multirow{2}{*}{$\begin{array}{l}\text { C stock } \\
\text { Mg ha }^{-1}\end{array}$} & \multicolumn{2}{|c|}{ C saturation deficit } & \multirow{2}{*}{$\begin{array}{l}\text { C stock } \\
\text { Mg ha- }^{-1}\end{array}$} & \multicolumn{2}{|c|}{ C saturation deficit } \\
\hline & & & $\mathrm{g} \mathrm{kg}^{-1}$ & $\mathrm{Mg} \mathrm{ha}^{-1}$ & & $\mathrm{~g} \mathrm{~kg}^{-1}$ & Mg ha $^{-1}$ \\
\hline \multirow[t]{10}{*}{ NF } & $0-2.5$ & $5.3(1.1)$ & $4.8(1.9)$ & $0.4(0.2)$ & $1.6(0.1)$ & $53.0(5.2)$ & $2.0(0.5)$ \\
\hline & $2.5-5$ & $5.2(0.4)$ & $13.9(1.0)$ & $1.4(0.2)$ & $1.6(0.3)$ & $69.7(1.1)$ & $3.7(0.9)$ \\
\hline & $5-10$ & $10.1(0.9)$ & $18.5(1.9)$ & $3.9(0.9)$ & $2.6(0.1)$ & 74.6 (1.9) & $8.1(1.0)$ \\
\hline & $10-20$ & $15.6(1.9)$ & $21.6(3.2)$ & $7.8(2.6)$ & $5.2(0.7)$ & $77.4(2.7)$ & $19.0(4.1)$ \\
\hline & $20-30$ & $14.7(1.5)$ & $25.6(5.3)$ & $9.4(2.4)$ & $4.6(0.6)$ & $80.5(3.9)$ & $20.6(3.2)$ \\
\hline & $30-40$ & $13.3(1.4)$ & $29.4(5.4)$ & $10.8(2.6)$ & $3.9(0.6)$ & $83.3(3.6)$ & $21.3(3.2)$ \\
\hline & $40-60$ & $25.3(4.5)$ & $33.0(5.9)$ & $25.6(5.9)$ & $7.0(1.0)$ & $85.7(3.6)$ & $46.6(8.9)$ \\
\hline & $60-80$ & $21.5(6.7)$ & $38.3(9.0)$ & $30.0(7.9)$ & $5.0(1.4)$ & $86.0(1.9)$ & $38.8(4.7)$ \\
\hline & $80-100$ & $17.5(6.7)$ & 45.1 (9.2) & $38.4(10.1)$ & $3.7(1.1)$ & 79.6 (13.5) & $35.2(7.2)$ \\
\hline & $0-100$ & $137.9(23.3)$ & & $127.9(26.9)$ & $35.3(3.8)$ & & $195.2(25.2)$ \\
\hline \multirow[t]{10}{*}{ NT } & $0-2.5$ & $3.7(0.4)$ & $16.4(0.4)$ & $1.6^{\mathrm{a}}$ & $1.9(0.5)$ & $12.1(0.3)$ & $-0.2^{\mathrm{a}}$ \\
\hline & $2.5-5$ & $4.9(0.7)$ & $16.9(1.2)$ & 0.3 & $2.5(0.5)$ & $12.5(0.9)$ & -0.9 \\
\hline & $5-10$ & $9.2(1.2)$ & $21.1(1.9)$ & 0.9 & $4.4(1.1)$ & $15.6(1.4)$ & -1.8 \\
\hline & $10-20$ & $19.5(1.6)$ & $23.8(0.4)$ & -3.9 & $7.2(0.1)$ & $17.6(0.3)$ & -2.0 \\
\hline & $20-30$ & $15.8(2.7)$ & $28.2(2.3)$ & -1.1 & $6.3(0.7)$ & $20.8(2.7)$ & -1.7 \\
\hline & $30-40$ & $14.4(2.2)$ & $31.9(3.3)$ & -1.1 & $5.7(0.8)$ & $23.6(2.5)$ & -1.8 \\
\hline & $40-60$ & $20.9(3.1)$ & $43.5(1.8)$ & 4.4 & $7.8(2.0)$ & $26.6(6.5)$ & -0.9 \\
\hline & $60-80$ & $21.9(3.3)$ & $40.0(0.8)$ & -0.4 & $8.1(2.1)$ & $28.8(0.8)$ & -3.0 \\
\hline & $80-100$ & $14.3(0.8)$ & $52.4(1.7)$ & 3.2 & $4.9(1.0)$ & $38.1(1.1)$ & -1.3 \\
\hline & $0-100$ & $124.7(13.6)$ & & 13.2 & 50.7 & & -13.5 \\
\hline \multirow[t]{10}{*}{ CT } & $0-2.5$ & $3.5(0.6)$ & $10.8(0.8)$ & $1.9^{\mathrm{a}}$ & $1.3(0.1)$ & $8.2(0.6)$ & $0.4^{\mathrm{a}}$ \\
\hline & $2.5-5$ & $4.1(0.9)$ & $10.5(1.0)$ & 1.1 & $1.6(0.1)$ & $8.0(0.8)$ & -0.1 \\
\hline & $5-10$ & $7.7(0.7)$ & $10.6(0.6)$ & 2.4 & $3.1(0.2)$ & $8.1(0.5)$ & -0.5 \\
\hline & $10-20$ & $16.3(1.8)$ & $10.8(0.7)$ & -0.7 & $6.0(0.4)$ & $8.2(0.6)$ & -0.8 \\
\hline & $20-30$ & $16.7(1.8)$ & $11.9(1.2)$ & -2.0 & $5.6(1.0)$ & $9.1(0.9)$ & -1.0 \\
\hline & $30-40$ & $14.8(3.0)$ & $16.8(4.8)$ & -1.5 & $4.8(0.8)$ & $10.7(0.0)$ & -0.9 \\
\hline & $40-60$ & $28.9(8.9)$ & $20.2(7.5)$ & -3.6 & $5.4(0.8)$ & $12.1(1.0)$ & 1.6 \\
\hline & $60-80$ & $27.2(3.4)$ & $18.6(0.7)$ & -5.7 & $7.2(2.7)$ & $14.2(0.8)$ & -2.2 \\
\hline & $80-100$ & $13.8(6.8)$ & $35.4(4.7)$ & 3.3 & $3.6(1.5)$ & $33.4(5.4)$ & 0.1 \\
\hline & $0-100$ & $132.9(24.1)$ & & 4.9 & $38.8(3.1)$ & & -3.4 \\
\hline
\end{tabular}

aCarbon saturation deficit calculated from the difference between the carbon stock in each physical fraction under native forest (NF) and under management systems (no-tillage - NT or conventional tillage - CT).

of the management systems in relation to the difference between the existent $\mathrm{C}$ stock under NF and under NT or CT management systems for both fractions.

In the Humic Hapludox, the introduction of NT management after 28 years of agricultural use increased the $\mathrm{C}_{\mathrm{sd}}$ by approximately $13.2 \mathrm{Mg} \mathrm{ha}^{-1}$ in the clay fraction at depths from 0 to $100 \mathrm{~cm}$, while in the LF-free silt fraction, it decreased by approximately $13.5 \mathrm{Mg} \mathrm{ha}^{-1}$. For the clay fraction, the negative values obtained for the 5 to $40 \mathrm{~cm}$ layers and the negative values obtained for LF-free silt indicate that these two fractions are storing more $\mathrm{C}$ than under NF management. Because the mineralogy is the same at both sites, one possible explanation for this result is the SOM stabilization via an SOM self-assemblage mechanism, where the SOM structures are sorbed on the already-sorbed SOM by organo-organo interactions. The LF-free silt fraction from the Humic Hapludox may represent an important fraction for the
C storage. Under CT management, the $\mathrm{C}_{\mathrm{sd}}$ for the whole profile was much smaller in the clay fraction $14.9 \mathrm{Mg}$ $\mathrm{ha}^{-1}$ ) than under NT management, and a negative value in the LF-free silt fraction was also observed (Table 4).

A different behavior was observed for the Rhodic Hapludox profile, where the $\mathrm{C}_{\text {sd }}$ was positive and varied from 21.3 to $34.0 \mathrm{Mg} \mathrm{ha}^{-1}$ in the clay fractions and did not differ in the silt fraction (Table 5). The clay fraction under CT management has a higher potential for further storing labile $\mathrm{C}$ than under NT management or than the LF-free silt fraction. For the Humic Hapludox, this behavior was observed in the clay fraction under NT management.

The calculated resistance index was 0.78 for the whole soil (data not shown) in the $0-20 \mathrm{~cm}$ layer (ploughing layer) of the Humic Hapludox. In this layer, the resistance indexes were 0.87 for the clay fraction and 1.09 for the LF-free silt fraction. The latter value, greater than 
Table 5 - Carbon stock and carbon saturation deficit in clay and LF-free silt fractions of a Rhodic Hapludox under native forest (NF), no-tillage (NT) and conventional tillage (CT) (values in parentheses refer to the standard deviation).

\begin{tabular}{|c|c|c|c|c|c|c|c|}
\hline \multirow{2}{*}{ System } & \multirow{2}{*}{ Depth } & \multicolumn{3}{|c|}{ Clay } & \multicolumn{3}{|c|}{ LF-free silt } \\
\hline & & \multirow{2}{*}{$\begin{array}{l}\text { C stock } \\
\text { Mg ha }^{-1}\end{array}$} & \multicolumn{2}{|c|}{ C saturation deficit } & \multirow{2}{*}{$\begin{array}{l}\text { C stock } \\
\text { Mg ha- }^{-1}\end{array}$} & \multicolumn{2}{|c|}{ C saturation deficit } \\
\hline \multirow{11}{*}{ NF } & $\mathrm{cm}$ & & $\mathrm{g} \mathrm{kg}^{-1}$ & $\mathrm{Mg} \mathrm{ha}^{-1}$ & & $\mathrm{~g} \mathrm{~kg}^{-1}$ & Mg ha-1 \\
\hline & $0-2.5$ & $4.7(0.3)$ & $2.8(1.9)$ & $0.3(0.2)$ & $2.6(1.0)$ & $45.3(8.8)$ & $2.8(0.7)$ \\
\hline & $2.5-5$ & $4.5(0.1)$ & $6.0(2.4)$ & $0.7(0.3)$ & $2.1(0.7)$ & $56.3(5.9)$ & $3.4(0.2)$ \\
\hline & $5-10$ & $9.9(1.8)$ & $12.8(3.7)$ & $4.0(0.8)$ & $3.9(1.1)$ & $68.6(4.6)$ & $10.4(0.4)$ \\
\hline & $10-20$ & $17.3(2.2)$ & $17.9(3.5)$ & $11.9(2.4)$ & $6.8(1.3)$ & 74.7 (3.7) & $24.4(0.5)$ \\
\hline & $20-30$ & $16.4(0.6)$ & $21.7(0.1)$ & $15.9(0.4)$ & $5.5(0.2)$ & $78.6(0.1)$ & $24.0(0.2)$ \\
\hline & $30-40$ & $15.1(1.0)$ & $23.5(0.7)$ & $17.2(0.0)$ & $4.9(0.4)$ & $80.2(0.6)$ & $24.4(0.4)$ \\
\hline & $40-60$ & $23.9(2.4)$ & $28.7(0.7)$ & $45.0(1.2)$ & $7.0(0.3)$ & $84.3(0.5)$ & $45.9(0.5)$ \\
\hline & $60-80$ & $19.0(2.0)$ & $31.7(0.8)$ & $48.9(0.6)$ & $5.4(0.5)$ & $86.4(0.6)$ & $46.1(0.5)$ \\
\hline & $80-100$ & $14.2(1.5)$ & $34.6(0.8)$ & $52.5(0.0)$ & $4.5(0.4)$ & $88.4(0.5)$ & $46.1(0.5)$ \\
\hline & $0-100$ & 124.9 (3.2) & & $196.4(6.0)$ & $45.0(2.0)$ & & $227.3(2.1)$ \\
\hline \multirow[t]{10}{*}{ NT } & $0-2.5$ & $2.4(0.3)$ & $1.8(0.2)$ & $2.3^{\mathrm{a}}$ & $1.4(0.1)$ & $8.5(0.3)$ & $1.2^{\mathrm{a}}$ \\
\hline & $2.5-5$ & $2.6(0.0)$ & $2.4(0.7)$ & 1.9 & $1.4(0.0)$ & $9.3(0.9)$ & 0.7 \\
\hline & $5-10$ & $6.4(0.7)$ & $4.9(0.1)$ & 3.5 & $3.3(0.2)$ & $12.3(0.1)$ & 0.7 \\
\hline & $10-20$ & $13.1(1.2)$ & $4.9(0.0)$ & 4.2 & $6.0(0.2)$ & $12.4(0.0)$ & 0.9 \\
\hline & $20-30$ & $12.1(0.8)$ & $6.8(0.2)$ & 3.4 & $5.3(0.3)$ & $14.5(0.2)$ & 0.2 \\
\hline & $30-40$ & $11.6(0.6)$ & $8.7(0.0)$ & 3.5 & $4.6(0.3)$ & $16.9(0.0)$ & 0.3 \\
\hline & $40-60$ & $21.5(0.3)$ & $10.6(0.1)$ & 2.5 & $6.7(0.5)$ & $19.5(0.1)$ & 0.3 \\
\hline & $60-80$ & $17.9(0.7)$ & $13.2(0.5)$ & 1.1 & $4.2(0.7)$ & $23.5(0.8)$ & 1.2 \\
\hline & $80-100$ & $15.2(1.0)$ & $15.1(0.8)$ & -1.0 & $2.4(1.0)$ & $27.0(1.5)$ & 2.1 \\
\hline & $0-100$ & $103.6(5.4)$ & & 21.3 & $35.0(2.8)$ & & 10.0 \\
\hline \multirow[t]{10}{*}{ CT } & $0-2.5$ & $1.9(0.4)$ & $5.5(0.1)$ & $2.8^{a}$ & $1.3(0.1)$ & 8.7 & $1.3^{\mathrm{a}}$ \\
\hline & $2.5-5$ & $2.2(0.4)$ & $5.4(0.3)$ & 2.3 & $1.4(0.1)$ & 8.6 & 0.7 \\
\hline & $5-10$ & $6.0(0.6)$ & $6.1(0.0)$ & 3.9 & $3.5(0.0)$ & 9.9 & 0.4 \\
\hline & $10-20$ & $11.0(0.8)$ & $7.6(0.2)$ & 6.3 & $5.9(0.1)$ & 11.8 & 0.9 \\
\hline & $20-30$ & $11.4(0.9)$ & $8.0(0.2)$ & 5.0 & $5.4(0.2)$ & 12.7 & 0.1 \\
\hline & $30-40$ & $10.7(0.6)$ & $9.2(0.2)$ & 4.4 & $4.9(0.0)$ & 14.6 & 0.0 \\
\hline & $40-60$ & $17.8(1.0)$ & $12.3(0.1)$ & 6.1 & $6.3(0.3)$ & 19.4 & 0.7 \\
\hline & $60-80$ & $16.8(2.2)$ & $13.5(1.4)$ & 2.2 & $4.6(1.0)$ & 21.2 & 0.8 \\
\hline & $80-100$ & 13.2 (1.9) & $16.3(0.6)$ & 1.0 & $2.1(0.4)$ & 25.8 & 2.4 \\
\hline & $0-100$ & $90.9(0.5)$ & & 34.0 & $35.4(0.9)$ & & 9.6 \\
\hline
\end{tabular}

aCarbon saturation deficit calculated from the difference between the carbon stock in each physical fraction under native forest (NF) and under management systems (no-tillage - NT or conventional tillage - CT).

the unity, indicates clearly that CT management did not affect the carbon storage in this fraction. However, the resistance index in the whole soil, lower than in the clay and LF-free silt indicates that the effect of CT management in reducing $\mathrm{C}$ storage occurred mainly in the particulate organic matter. In the Rhodic Hapludox, the resistance indexes in the $0-20 \mathrm{~cm}$ depths obtained for the whole soil $(0.60)$ and fractions (0.58 for clay and 0.79 for LF-free silt) were smaller than the unity and lower than the values calculated for the Humic Hapludox. These results confirm that this soil is less resistant to the impact of CT management in comparison to the Humic Hapludox with respect to $\mathrm{C}$ storage, as already discussed regarding the $\mathrm{C}$ concentration. Furthermore, they show that the mineral-associated SOM is strongly affected by the change of land use in the Rhodic Hapludox.

The resilience index calculated was 0.63 in the 0-20 cm layer of the whole Humic Hapludox. In the clay fraction of the first $20 \mathrm{~cm}$ of this soil, the resilience index (1.26) greater than the unity indicates that the increase in the $\mathrm{C}$ stock resulting from the introduction of NT management surpassed the amount of $\mathrm{C}$ lost by the previous CT management. The $\mathrm{C}$ stock in LF-free silt in the $0-20 \mathrm{~cm}$ layer was greater under CT than under NT management (data not shown), resulting in a negative value for the resilience index (-3.90) and confirming the value as $>1.00$ obtained for the resistance index. For the Rhodic Hapludox, the values for the resilience indexes for the whole soil (0.11), clay fraction (0.11) and LF-free silt (-0.03) suggest a low capacity for $\mathrm{C}$ recovery in the whole soil and fractions. These results, compared to those obtained for the Humic Hapludox, indicate that the latter is highly resilient; this fact may be due to the reactivity of the mineral surface and climatic conditions, both favorable for $\mathrm{C}$ sequestration in the Guarapuava region. 


\section{Conclusions}

The NT system promotes the increase of C retention capacity in comparison to that under CT in the Humic Hapludox. In contrast, the Rhodic Hapludox showed no difference in $\mathrm{C}$ retention capacity under both management systems.

Possibly it is the cooler climate that slows down the residue mineralization and thus enables the stabilization of SOM through sorption mechanisms in the $\mathrm{Hu}$ mic Hapludox leading to the higher capacity of physical fractions under NT to retain C by organo-mineral interactions and organo-organo associations. In the Rhodic Hapludox, no difference in $\mathrm{C}$ retention capacity in the physical fractions regarding the management system was observed possibly due to the faster mineralization of SOM promoted by the higher temperatures in this region.

The greater $\mathrm{C}$ retention capacity of a given physical fraction of the Humic Hapludox might be explained by the predominance of goethite and gibbsite, which have a higher density of sorption sites for SOM in comparison to the Rhodic Hapludox which is composed mainly by hematite and kaolinite.

\section{Acknowledgements}

To the Coordination for the Improvement of Higher Level Personnel (CAPES), the Research Support Foundation of the State of Rio Grande do Sul (FAPERGS) and the Brazilian National Council for Scientific and Technological Development (CNPq).

\section{References}

Angers, D.A.; Arrouays, D.; Saby, N.P.A.; Walter, C. 2011. Estimating and mapping the carbon saturation deficit of French agricultural topsoils. Soil Use and Management 27: 448-452.

Boddey, R.M.; Jantalia, C.P.; Conceição, P.C.; Zanatta, J.A.; Bayer, C.; Mielniczuk, J.; Dieckow, J.; Santos, H.P.; Denardin, J.E.; Aita, C.; Giacomini, S.J.; Alves, B.J.R.; Urquiaga, S. 2010. Carbon accumulation at depth in Ferralsols under zero-till subtropical agriculture. Global Change Biology 16: 784-795.

Campos, B.H.C.; Amado, T.J.C.; Bayer, C.; Nicoloso, R.S.; Fiorin, J.E. 2011. Carbon stocks and its compartiments in a subtropical oxisol under long-term tillage and a crop rotation systems. Revista Brasileira de Ciência do Solo 35: 805-817.

Carrington, E.M.; Hernes, P.J.; Dyda, R.Y.; Plante, A.F.; Six, J. 2012. Biochemical changes across a carbon saturation gradient: lignin, cutin, and suberin decomposition and stabilization in fractionated carbon fractions. Soil Biology and Biochemistry 47: 179-190.

Costa, F.S.; Albuquerque, J.A.; Bayer, C.; Fontoura, S.M.V.; Wobeto, C. 2003. Physical properties of a south Brazilian Oxisol as affected by no-tillage and conventional tillage. Revista Brasileira de Ciência do Solo 27: 527-535 (in Portuguese, with abstract in English).
Costa, F.S.; Bayer, C.; Albuquerque, J.A.; Fontoura, S.M.V. 2004. No-tillage increases soil organic matter in a south Brazilian Oxisol. Ciência Rural 34: 587-589 (in Portuguese, with abstract in English).

Dieckow, J.; Bayer, C.; Conceição, P.C.; Zanatta, J.A.; Martin-Neto, L.; Milori, D.M.B.P.; Salton, J.C.; Macedo, M.M.; Mielniczuk, J.; Hernani, L.C. 2009. Land use, tillage, texture and organic matter stock and composition in tropical and subtropical Brazilian soils. European Journal of Soil Science 60: 240-249.

Diekow, J.; Mielniczuk, J.; Knicker, H.; Bayer, C.; Dick, D.P.; Kögel-Knabner, I. 2005. Carbon and nitrogen stocks in physical fractions of a subtropical Acrisol as influenced by long-term no-till cropping systems and $\mathrm{N}$ fertilization. Plant and Soil 268: 319-328.

Ellert, B.H.; Bettany, J.R. 1995. Calculation of organic matter and nutrients stored in soils under contrasting management regimes. Canadian Journal of Soil Science 75: 529-538.

Inda Junior, A.V.; Bayer, C.; Conceição, P.C.; Boeni, M.; Salton, J.C.; Tonin, A.T. 2007. Selected soil-variables related to the stability of organo-minerals complexes in tropical and subtropical Brazilian soils. Ciência Rural 37: 1301-1307 (in Portuguese, with abstract in English).

Jagadamma, S.; Lal, R. 2010. Distribution of soil carbon in physical fractions of soils as affected by agricultural management. Biology and Fertility of Soils 46: 543-554.

Kaiser, K.; Guggenberger, G. 2000. The role of DOM sorption to mineral surfaces in the preservation of organic matter in soils. Organic Geochemistry 31: 711-725.

Kleber, M.; Sollins, P.; Sutton, R. 2007. A conceptual model of organo-mineral interactions in soils: self-assembly of organic molecular fragments into zonal structures on mineral surfaces. Biogeochemistry 85: 9-24.

Potes, M.L.; Dick, D.P.; Santana, G.S.; Tomazi, M.; Bayer, C. 2012. Soil organic matter in fire-affected pastures and in an Araucaria forest in south-Brazilian Leptosols. Pesquisa Agropecuária Brasileira 47: 707-715 (in Portuguese, with abstract in English).

Roscoe, R.; Buurman, P.; Velthorst, E.J.; Vasconcellos, C.A. 2001. Soil organic matter dynamics in density and particle-size fractions as revealed by the ${ }^{13} \mathrm{C} /{ }^{12} \mathrm{C}$ isotopic ratio in a Cerrado's Oxisol. Geoderma 104: 185-202.

Schwertmann, U.; Taylor, R.M. 1977. Iron oxides. p. 145-180. In: Dixon, J.B.; Weed, S.B., eds. Minerals in soil environments. Soil Science Society of America, Madison, MI, USA.

Six, J.; Conant, R.T.; Paul, E.A.; Paustian, K. 2002. Stabilization mechanisms of soil organic matter: implications for C saturation of soils. Plant and Soil 241: 155-176.

Soil Survey Staff. 2010. Keys to Soil Taxonomy. 11ed. USDANRCS, Washington, DC, USA.

Stewart, C.E.; Paustian, K.; Conant, R.T.; Plante, A.F.; Six, J. 2007. Soil carbon saturation: concept, evidence and evaluation. Biogeochemistry 86: 19-31.

Stewart, C.E.; Paustian, K.; Conant, R.T.; Plante, A.F.; Six, J. 2008. Soil carbon saturation: evaluation and corroboration by longterm incubations. Soil Biology and Biochemistry 40: 1741-1750.

Stewart, C.E.; Paustian, K.; Conant, R.T.; Plante, A.F.; Six, J. 2009. Soil carbon saturation: implications for a measurable carbon fraction dynamics in long-term incubations. Soil Biology and Biochemistry 41: 357-366. 